\title{
ASSISTANCE IN IMPROVING QUALITY OF EDUCATION IN EARLY CHILDREN BASED ON STANDARD PAUD IN DELI SERDANG DISTRICT
}

\author{
Sariana Marbun \\ Faculty of Education, Medan State University, Medan, Indonesia \\ *Corresponding Author: Sariana.marbun1961@gmail.com
}

\begin{abstract}
Activities in Quality Improvement of ECD Management Based on ECD Standards based on the low understanding of managers (principals and teachers) on eight PAUD Standards (Standards for Achieving Child Development, Content, Processes, Educators and Education Personnel, Assessment, Facilities and Infrastructure, Management and Financing). This activity aims to assist principals and teachers in managing PAUD based on PAUD standards. The activities carried out began with enlightenment and question and answer about the Nature of PAUD Standards, then analyzed the Instruments for PAUD Quality Mapping, and Assistance in completing the documents of each Standard. Mentoring activities were carried out from August to October 2018, which took place at PAUD Miska and PAUD Harapan Bangsa, Percut Sei Tuan District, Deli Serdang Regency. The participants of this activity were the Principal and Teachers and Education Personnel who served in the two schools totaling 10 people. Activities are carried out by means of discussion, question and answer, group work and assignments. At the end of the activity an evaluation of the process and work results of the participants was conducted, and agreed on follow-up activities from mentoring. The results of the mentoring activities concluded that: 1) Understanding of Principals and teachers and other education personnel about PAUD management Based on PAUD Standards increased; 2) Managers' lack of understanding of PAUD Standards causes a lack of realization of programs that refer to standards, lack of procurement of facilities and infrastructure, and not storing documents or letter files, certificates, photos, attendance lists and others. It is recommended that PAUD managers try to rediscover some of the physical evidence that the activities that have been carried out are in accordance with the standards, and the following day the manager must carry out the program in accordance with the PAUD Standards.
\end{abstract}

Keywords: Assistance in Quality Improvement of PAUD Management, PAUD Standards.

\section{INTRODUCTION}

Early Childhood Education (PAUD) is a coaching effort aimed at children from birth to 6 years which is carried out through educational stimuli to help growth and physical and spiritual development in order to have readiness to learn in entering further education. Some of the important reasons for PAUD include: "a) PAUD is the initial foundation in improving the ability of children to complete higher education, reducing the number of repetition classes and dropout rates; b) PAUD is an investment that benefits both the family and the government; c) PAUD is an effort to stop the wheel of poverty; c) PAUD is the right of every child to obtain education guaranteed by the Constitution "(UNESCO).

There are various types of educational institutions or PAUD units in Indonesia that can accommodate early childhood to be educated in accordance with the objectives of early childhood education. With the enactment of the Minister of Education and Culture Regulation No. 137 of 2014 concerning the National Standards for Early Childhood Education, the forms of PAUD programs in Indonesia are, Kindergarten (TK) / Raudatul Athfal (RA) / Bustanul Athfal (BA), Play Group (KB), Child Care Park (TPA), and Similar Early Childhood Education Unit (SPS). Management and implementation of all types of PAUD units must be in accordance with PAUD National Standards. The PAUD National Standard is referred to as the PAUD Standard is a criterion for PAUD management and organization in all jurisdictions of the Unitary State of the Republic of Indonesia. PAUD standards function as: "(a) the basis in planning, implementing, monitoring and following up on education in order to realize quality PAUD; (b) reference to every PAUD unit and program to realize national education goals; (c) the basis of quality assurance "(Chapter II, article 3).

The rapid growth of PAUD units in the community at this time, when viewed in terms of quantity, is sufficient to accommodate the number of early childhoods who will be given education. However, in terms of the quality of management, it turns out that it still has not reached the expected standard. Based on existing data, especially in North Sumatra (HIMPAUDI Sumut) and data from the results of research by lecturers and students, it shows that the 
implementation of PAUD units established by the community, especially in North Sumatra, about $70 \%$ of its management is still not in accordance with PAUD Standards.

This condition occurs in PAUD units who are partners in the Community Service Program of Unimed LPM, namely Harapan Bangsa PAUD (established in 2008) and PAUD / TK Miska (established in 2010) located in Percut Sei Tuan District, Deli Serdang Regency. The two partner institutions in managing PAUD seem to have tried to implement school programs optimally, but in the management and implementation of PAUD managers they did not fulfill the requirements required in the 8 PAUD National Standards. So that until now the manager has not been able to apply for accreditation to the PAUD National Accreditation Agency. The high desire of PAUD managers and educators so that their institutions have good accreditation, but they do not understand the steps that should be taken in implementing each PAUD Standard.

In general, the problems faced by partner schools are the same, namely relating to: a) Insufficient understanding of eight PAUD Standards (Child Development Achievement Standards; Content Standards; Process Standards; Assessment Standards; Educators and Education Personnel Standards; Infrastructure Standards; Standards Management and Standardization of Financing In particular some of the problems that appear are: a) The operational curriculum is not in accordance with the guidelines for the preparation of the Education Unit Level Curriculum (KTSP), such as semester, weekly and daily programming; b) In learning it is very priority for children to be able to read, write and count, using classical learning models, so that the development of other aspects (social-emotional, artistic, motoric) is almost neglected; c) Has not implemented a program that contains Integrative Holistic elements which include health, nutrition, care, and protection; d) In evaluating children's development, the teacher does not use assessment instruments in accordance with the developmental aspects assessed during the child's education; e) Educational games both in class and outside the class that are still lacking, and in learning prioritize children learning through children's books or worksheets purchased from printing; f) Educators in both institutions have not all fulfilled Krteria as PAUD Educators; g) The two schools have never socialized the Vision, Mission and objectives of the School, as well as the Annual Program to the community, whether through face-to-face meetings, leaflets, brochures and others, so that the community is less involved in PAUD programs; h) Various activities carried out by the school each year, such as meetings with PAUD teachers, workshop activities, etc., but the manager and the teacher do not store activity documents, such as letters, certificates, attendance lists of meeting participants. and other activities, so that there is no physical evidence that the school has ever carried out activities.

Mentoring activities aim to assist PAUD managers and teachers in understanding every aspect demanded in eight PAUD standards, assisting managers and teachers in preparing all the required documents for each standard.

Based on the PAUD quality mapping instrument published by the Directorate General of PAUD and Community Education (2017), the PAUD standard that must be met by each PAUD unit is as follows:

1) Standard Level of Achievement of Child Development (STPPA), which is a criterion of ability achieved by children on all aspects of development and growth that includes aspects of Religious Values and Morals, Physicalmotoric, Cognitive, Language, Social-emotional, and arts. Schools must have documents on the achievement of child development according to the age group, and be documented in the form of daily, weekly, monthly and semester recordings.

2) Content Standards are; criteria about the scope of material and competency to the level of achievement that is appropriate for early childhood. Schools must have an operational curriculum that refers to local, national or international standards, and there are school efforts to review the curriculum according to the specified time limit. Schools must determine the scope of the material according to the age group, as well as the learning burden according to the age group. The school must have an education calendar, and the education calendar must be socialized to parents.

3) Process Standards are criteria for implementing learning in PAUD units or programs in order to help fulfill the level of developmental achievement in accordance with the age level of the child. Schools must have a learning process planning that includes semester activity plans, weekly and daily activity plans, and holistic integrative programs. In the implementation of learning PAUD educators must be able to organize a child's playing environment that is safe, comfortable, clean, healthy and attractive. Chase must be organized through activities in the classroom and outside the classroom, and carried out through 3 main activities (opening, core, and closing). Assessment of children is done through the assessment of processes and results, and techniques used through observation, anecdotal records, and work.

4) Assessment Standards are criteria regarding the assessment of learning processes and outcomes in order to know the level of achievement that is in accordance with the age level of the child. Schools must have assessment guidelines before evaluating children, carried out with certain techniques, and the results of the assessment must be reported to parents with the frequency of reports every week, every month, every semester, and every year.

5) Standards for Educators and Education Personnel are criteria regarding academic qualifications and competencies required for PAUD educators and education staff. The school must have documentation of the qualifications of 
the teaching staff and education, the competencies possessed, the type and time / duration of the training followed by the teaching staff.

6) Standard for Facilities and Infrastructure is criteria for supporting requirements for the implementation and management of PAUD in a holistic and integrative manner that utilizes local potential. The facilities that must be possessed by PAUD institutions are facilities for playing outside and playing games in the room according to the type and shape of the game, namely playing buildings, playing roles, playing sensory motorbikes, playing literacy, and playing art. The infrastructure that must be owned is land area $(2500 \mathrm{~m} 2)$, has the type and number of rooms such as study rooms / classrooms, teacher rooms, toilets, warehouses and function rooms. Every institution must have electricity, telephone, internet, etc.

7) Management Standards are criteria for planning, implementing and monitoring educational activities at the unit level or PAUD program. Each institution must have a vision, mission, and goals and must be socialized to parents through meetings, or through print media (levies, brochures, etc.) and documented in schools. Must have an annual, five-year work plan. PAUD units must have an organizational structure and assignment description us to have a basic unit in each personnel listed in the organizational structure. PAUD units must have a network of partnerships with other parties. PAUD units must have guidebooks (learning, facilities and infrastructure, parents), must have administrative books (children, cash books, inventory of goods, guest books, etc.), must have a management information system (bulletin board, books unit guide, and print media). PAUD units must supervise the process and results of program implementation on a regular basis, and monitoring reports must be made. The overall results of the investigation must be documented.

8) Financing Standards are criteria about the components and the amount of personal and operational costs in PAUD units or programs. PAUD units must plan the type of financing to be issued, it must be clear the source of funds each year (foundations, government, parents, companies, etc.), report on the use of funds, and have accounting related to the funding owned by PAUD units.

\section{IMPLEMENTATION METHOD}

Mentoring activities in improving the quality of PAUD Standard-based PAUD management were carried out in Miska PAUD / TK in Percut Sei Tuan District, Deli Serdang Regency. Activities start from July to October 2018. Participants in the event are 10 teachers ( 2 principals, 1 head of foundation, 1 school operator and 6 teachers from 2 PAUD units. The methods applied during the activity are: Questions and answers, discussions, assignments, and simulations The activities are carried out through three stages, namely: (1) Preparation Phase, (2) Implementation Phase, and (3) Closing Phase. a number of 3 lecturers from different fields of expertise and brought material in accordance with their respective fields of expertise and assisted by 2 students

The preparation stage is an activity that is carried out to prepare all the needs of mentoring activities such as the preparation of activity schedules, material activities, data collection instruments, tools needed during mentoring activities. The implementation phase is all mentoring activities carried out for PAUD teachers whose steps are as follows: 1) Questions and answers and class discussions about eight PAUD National Standards; 2) Assistance in analyzing the PAUD Quality Mapping Instrument which concerns eight PAUD Standards; 3) Assistance in completing the eight PAUD Standards documents. Mentoring to analyze instruments and complete the requested documents in each standard is done in stages, meaning that each time the meeting analyzes two standards, so the activity of analyzing the instrument and completing the eight PAUD standard documents is carried out during 4 meetings. Next is a simulation of the way the manager answers the questions if he is facing an Assessment Team from the PAUD Accreditation Agency. In the closing stages, the activities carried out were evaluating the process and results and reflecting on the tasks that had been carried out by the principal and the teacher and the team in the overall mentoring activities.

\section{RESULTS AND DISCUSSION}

The results of activities obtained during mentoring are:

1) The participants of the activity (the principal and teacher) gain a clear understanding of each PAUD Standard, it seems that all participants enthusiastically listened to the explanation of the resource person, asked questions if participants were not clear and were able to answer the questions posed in the Quality Mapping instrument PAUD Education.

2) From a number of questions contained in the PAUD Quality Mapping instrument, many questions that cannot be answered are in the Content, Process, Assessment and Management standards, because the activities requested by the instrument are not carried out by the school.

3) Not all documents requested on each Standard are owned by the two partner schools. Example: a) At the Standards of Achievement of Child Development (Standard 1) schools only have Permendikbud number 137 of 2014, have not specifically packaged the achievement of child development in accordance with the development asper and the age level of their students, and there are no documentary records of children's progress for each day , week and monthly; b) the school has KTSP but the KTSP document is not relevant to the standard demands of a curriculum; c) Children's play facilities that are not sufficient for the development of all aspects of a child's development. To 
procure educational educational tools for school principals and teachers, they can work together to make playground equipment using used materials, not having to buy expensive.

4) Teachers who have a high school education qualification still need training as stipulated in the Minister of Education and Culture regulation 137, which must follow tiered training (basic, advanced and advanced level). The training that the teacher has participated in is not the context of the three levels, and the training certificate that has been followed is not documented in the school.

5) Schools every year carry out activities such as competitions, meetings with parents, bringing children to field trips, but schools do not have documents on all activities that have been carried out such as parent attendance lists, certificates from places of children's field trips, certificates, and others. As well as photos of activities both at school and at school.

6) The lack of understanding of PAUD managers (principals and teachers) on each indicator in eight PAUD standards and lack of clarity in documenting everything needed at each standard is the reason for the lack of documentation that the school has.

Mentoring activities in improving the quality of PAUD-based PAUD-based management of PAUD for managers / principals and teachers are needed for the continuity of quality early childhood education processes. The fact shows that there are still many managers and founders of PAUD units in organizing PAUD who do not pay attention to the requirements that must be fulfilled as PAUD institutions. Along with the government's concern for early childhood education, and with the rapid development of the presence of PAUD units in the community and the care of parents for early childhood education, it is the basis for every PAUD unit to always carry out self-evaluations of programs that have been carried out, improved and improve the quality of school facilities and infrastructure which are all geared towards PAUD National Standards. To help smooth the management of PAUD units so that they can accelerate their institutions in Accreditation, principals should form a school quality assurance team, and this must involve all teachers. Each teacher is given the task of answering certain standards, being the principal as coordinator and facilitator for all the tasks the teacher is working on in relation to the standards being worked on.

The principal and the teacher set the time for the meeting to evaluate the performance of the teacher in order to carry out school programs and in collecting documents for school accreditation. If possible, the principal invites the Accreditation Team in his area, for example, in Deli Serdang Regency to find out how far the school has performed in order to improve the quality of its school management.

The government's concern for early childhood education has not been balanced with the government's attention to improving the quality of human resources both teachers and principals in PAUD units, and improving the quality of facilities and infrastructure needed for PAUD. Therefore, the Head of the Foundation and the Principal should collaborate with private institutions such as companies, printing and collaboration with professional organizations such as the Association of Early Childhood Educators and Education Personnel (HIMPAUDI), Indonesian Kindergarten Teachers Association (IGTKI), and others, to improve the quality of management of PAUD units that they develop.

\section{CONCLUSION}

The conclusions obtained from the activities of Quality Improvement Assistance for PAUD Management based on PAUD National Standards are: 1) Quality PAUD is if the organization is managed well and follows standardized rules as an Early Childhood Education institution; 2) A clear understanding of the concept of PAUD Standards will make it easier for managers to realize the demands that must be met by each PAUD Unit; 3) Good cooperation between school principals, foundations and teachers is needed for the implementation of quality PAUD units; 4) Procurement of educational games that are needed to stimulate children's development should be the attention of managers and teachers in PAUD units, given the principle of learning early childhood while playing.

\section{REFERENCES}

Directorate General of Early Childhood Education and Community Education, 2017. Quality Mapping Instrument for ECD, Central Jakarta.

Jackman Hilda L, 2009. Early Education Curriculum; A Child Connection to the World, USA, Delmar Cengage Learning

Musfah Jejen, 2012. Holistic Education; Lintas Persfektif approach, Jakarta, Prenada Media Group

Puckett Margaret B. \& Diffily Deborah, 2004. Teaching Young Children; An Instruction to the Early Childhood Profession, Canada, Thomson Delmar Tearning.

Permendikbud No. 137 of 2014. concerning National Standards for Early Childhood Education. Jakarta

Permendikbud No. 146 of 2014. Jakarta concerning 2013 Curriculum for Early Childhood Education. Jakarta

Usman Husnaini, 2011. Management; Educational Theory, Practice and Research, Jakarta, Bumi Aksara

Law No. 20 of 2003 concerning the National Education System. Jakarta.

Law No. 14 of 2005 concerning Teachers and Lecturers. Jakarta 